\title{
Watergate and White House Tapes
}

The Watergate-case, which became a symbol of using surveillance technologies aimed at disabling political opponents, refers to a highly publicized political scandal in the US, which eventually led to the resignation of the President. The case focused public attention both on misusing campaign-money as well as the abusive use of surveillance technologies.

The use of surveillance mechanisms in the Watergate scandal involved numerous attempts to wiretap political rivals and unwelcomed civil activists, as well as the White House cloaking these operations by the help of the FBI and CIA. The case also involves surveillance by the President.

Facts of the case

On June 17, 1972 five men, Bernard Barker, Virgilio Gonzalez, Eugenio Martinez, Frank Sturgis, and James W. McCord Jr. were arrested in the Watergate complex in Washington D.C. while attempting to install listening devices and photographing documents in the offices rented by the Democratic National Committee. Two investigative journalists, Bob Woodward and Carl Bernstein linked the burglars to members of Richard Nixon's presidential reelection campaign, thus the incident was traced back to the White House.

Criminal investigation for the burglary

During the subsequently started criminal investigations McCord, a former CIA agent, admitted that he was hired by the Republican National Committee and the Committee to ReElect the President (CRP, later nicknamed as CREEP). He claimed to have been contacted by White House counsel John Dean, and confirmed that Jeb Stuart Magruder, Deputy Director of the CREEP was also involved in the burglary. During the investigations John N. Mitchell, Campaign Director of the CREEP, has been found to have access to a secret fund, dedicated to spying on Democratic presidential candidates. John Erlichman, Assistant to the President for Domestic Affairs and Harry Robbins Haldeman, White House Chief of Staff were also involved in the case. L. Patrick Gray, acting Director of the FBI pleaded that he provided documents related to the Watergate investigation to John Dean.

The criminal trial of the five burglars and two accomplices began on January 8, 1973. Five of them plead guilty; two were convicted by a jury. Chief Federal District Judge John Sirica held that not all the facts had been revealed and urged the defendants to cooperate with the Senate Select Committee which was due to be established in the near future.

On February 7, 1973, the Senate convened a committee led by Sam J. Ervin (Select Committee on Presidential Campaign Activities) in order to investigate the burglary and ensue the scandal. Its hearings became a nationwide media event and as a result of the activity of the Committee, 40 government officials were indicted.

The hearings also revealed the "Huston Plan", a security operation, which called for the wiretapping and microphone-surveillance of political "radicals". The proposed plan had been considered as clearly unconstitutional by both Mitchell and FBI Director J. Edgar Hoover, and subsequently had been withdrawn by President Nixon.

The Saturday Night Massacre

The term Saturday Night Massacre was used for the day (and night) of October 20, 1973 when President Nixon achieved the dismissal of special prosecutor Archibald Cox and accepted the resignation of Attorney General Richardson and Deputy Attorney General William Ruckelshaus. 
On July 16, 1973, White House aide Alexander Butterfield testified that all of Nixon's conversations in the White House had been taped at the President's orders in the time period which included the Watergate cover-up. The special prosecutor, who was appointed by Richardson in May, requested the District Court to subpoena the relevant tapes, but the President refused to release them. Nixon offered a compromise asking Senator John C. Stennis to summarize the tapes for the prosecutor's office. Cox refused the offer which resulted that Nixon ordered the Attorney General to dismiss Cox. Though the special prosecutor is under the authority of the Attorney General, he can only be removed "for cause". Richardson resigned as well, and so did Ruckelshaus. Finally Cox was dismissed by Robert Bork, acting head of the Justice Department.

Nixon's strategy proved to be counterproductive, as the public opinion turned against him: according to NBC News, the plurality of American citizens would ave supported impeachment with $44 \%$ in favour, $43 \%$ opposed and $13 \%$ undecided. Ten days later the impeachment proceedings began and the House of Judiciary Committee started its investigations.

\section{The White House Tapes Supreme Court decision}

Leon Jaworski, the next subsequent special prosecutor appointed by Cox in November 1973, also refused to accept the edited transcripts of the recordings and subpoenaed the original tapes. The President appealed against the subpoena on two grounds: first, that the office of the Special Prosecutor did not have the right to sue the office of President; and secondly that the requested materials were privileged presidential conversations. Jaworski, being aware of the constitutional importance of the case, requested the Supreme Court to take the case directly. In the spring of 1974 the White House released 1254 pages of edited transcripts of 20 tapes. In July 1974 the Supreme Court in its decision United States v. Nixon (418 U.S. 683 (1974)) held that "neither the doctrine of separation of powers nor the generalized need for confidentiality of high-level communications, without more, can sustain an absolute, unqualified Presidential privilege of immunity from judicial process under all circumstances."

Following the decision, the White House handed over numerous tapes, but the recordings contained erasures which altogether formed an approximately 18,5 min. long gap. The blank gap occurred on a recording of the conversation between Nixon and Haldeman, taped only three days after the Watergate break-in. Reasons were never given for the erasure, but experts concluded that they were intentional.

\section{The Smoking Gun}

One of the released tapes, recorded six days after the scandal erupted, revealed a conversation between the President and Haldeman discussing how to cover up the involvement of the White House in the scandal. After the tape was made public, Nixon's political support vanished. By this time, the House Judiciary Committee finalized the impeachment, charging Nixon with obstruction of justice, abuse of power, and contempt of Congress. The impeachment stated that the President misused the FBI, the Secret Service and other executive personnel in order to "conduct or continue electronic surveillance or other investigations for purposes unrelated to national security." Leading Republican politicians informed Nixon that his removal was unavoidable. He resigned the presidency in order to avoid losing the impeachment vote and risking a trial in the Senate.

Emese Szilagyi - Andras L. Pap

Hungarian Academy of Sciences Centre for Social Sciences, Budapest 
See Also: Foreign Intelligence Surveillance Act [FISA]; Hoover, J. Edgar (uses and abuses of surveillance,); Nixon, Richard M. (Administration); Scandals, Political (e.g., Anthony Weiner); White House.

\section{Further Readings}

Friedman, Leon and Levantrosser, William F. (ed.) Watergate and Afterward: The Legacy of Richard M. Nixon. Westport, Connecticut - London: Greenwood Press, 1992.

Kutler, Stanley I. (ed.) Watergate - A Brief History With Documents. Chicester: WileyBlackwell, 2009.

Miller, Stephen Paul. (ed.) The Seventies Now: Culture as Surveillance. Durham, [N.C.]: Duke University Press, 1999.

Stolz, Barbara Ann. "The Foreign Intelligence Surveillance Act of 1978: The Role of Symbolic Politics." Law and Policy, v.24/3, (2002).

United States v. Nixon, 418 U.S. 683 (1974). 